Dialectologia. Special issue, $\boldsymbol{V}$ (2015), 241-260.

ISSN: 2013-2247

Received 3 March 2015.

Accepted 28 May 2015.

\title{
ALLOCUTIVE PRONOUNS IN ANDALUSIA AND THEIR TENDENCY TOWARD STANDARDISATION
}

\author{
Víctor LARA BERMEJO \\ Universidad Autónoma de Madrid \\ viktoresc@hotmail.com
}

\begin{abstract}
In this paper, I will present the social and linguistic evolution of a Spanish phenomenon that has not been researched in depth. The usage of one single pronoun to address a second person plural is attested in the southern Spanish region of Andalusia and it induces both $2^{\text {nd }}$ person and $3^{\text {rd }}$ person agreements, differing from the standard pattern. However, this phenomenon is stigmatised and we do not count with an exhaustive study on its actual area nor the social characteristics of the speakers who may use it. In this article, I will show the current geographic extension of this feature, as well as the social parameters which the adoption or not of the prestigious form depends on.
\end{abstract}

\section{Keywords}

standardisation, Andalusia dialect, allocutives

\section{PRONOMBRES ALOCUTIVOS EN ANDALUCÍA Y SU TENDENCIA A LA NORMALIZACIÓN}

\section{Resumen}

En este artículo, presentamos la evolución social y lingüística de un fenómeno del español que no ha sido investigado en profundidad. El uso de un solo pronombre para la segunda persona del plural se manifiesta en la región meridional de Andalucía e induce concordancias de persona de segunda y tercera, desobedeciendo el estándar. Sin embargo, este fenómeno está estigmatizado y no contamos con un estudio exhaustivo sobre la verdadera área y las características sociales de los hablantes que 
incurren en este fenómeno. Es por ello que aquí presentamos su extensión geográfica actual así como los parámetros sociales de los que depende la adopción de la forma prestigiosa o su rechazo.

Palabras clave

estandarización, dialecto andaluz, alocutivos, concordancia

\section{Outline}

In this paper I will present the levelling of second person plural pronouns in Andalusia (Spain) and its person agreement mismatches. The last information available can be found in linguistic atlases from the first half of the $20^{\text {th }}$ century, whose methodology could have tainted in the informant's responses. In order to research the evolution of this particularity and the real social factors that intervene in the selection of the person agreement, I will show the data obtained thanks to a new and innovative methodology carried out recently. I will argue that the educational background, as well as the geographic location and the size of the population of the municipalities surveyed, are crucial for the selection of the vernacular phenomenon or the standard pattern. I will defend that there is a clear tendency toward standardisation and that this process is being led by middle-aged women from urban environments.

\section{Introduction}

Second person pronouns in Spanish distinguish perfectly the number of addressees and the degree of politeness. There are four: two singular, two plural. For each grammatical number, there is one for formality and another one for informality (see Table 1).

\begin{tabular}{|l|l|l|}
\hline & Singular & Plural \\
\hline Formality & Usted & Ustedes \\
\hline Informality & Tú & Vosotros \\
\hline
\end{tabular}

Table 1. Standard second person pronouns 
All informal pronouns induce $2^{\text {nd }}$ person inflections, whereas formal pronouns must agree in $3^{\text {rd }}$ person (see Table 2). This is the standard usage in peninsular Spanish or Spanish spoken in the Iberian Peninsula (Spain, except the Canary Islands).

\begin{tabular}{|l|l|l|}
\hline & Singular & Plural \\
\hline Formality & $3^{\text {rd }}$ person & $3^{\text {rd }}$ person \\
\hline Informality & $2^{\text {nd }}$ person & $2^{\text {nd }}$ person \\
\hline
\end{tabular}

Table 2. Standard person agreement for second person pronouns

However, at one point in history, the western part of Andalusia, the most southern region in Spain, eliminated the $2^{\text {nd }}$ person plural pronoun, vosotros, and has levelled in ustedes any $2^{\text {nd }}$ person plural, regardless the formality or the informality. In spite of this particularity, Lara (2010) has proved that ustedes can agree both in $2^{\text {nd }}$ and $3^{\text {rd }}$ person plural with verbs, clitics or possessives (see Table 3). These agreement mismatches between the stressed pronoun and the other syntactic elements anchoring ustedes, have not been explained nor investigated in depth for the time being.

\begin{tabular}{|l|l|l|}
\hline & Stressed pronoun & Clitics, verbs, possessives \\
\hline Formality & Ustedes & $2^{\text {nd }} / 3^{\text {rd }}$ person \\
\hline Informality & Ustedes & $2^{\text {nd }} / 3^{\text {rd }}$ person \\
\hline
\end{tabular}

Table 3. Andalusia second person plural pronouns system 


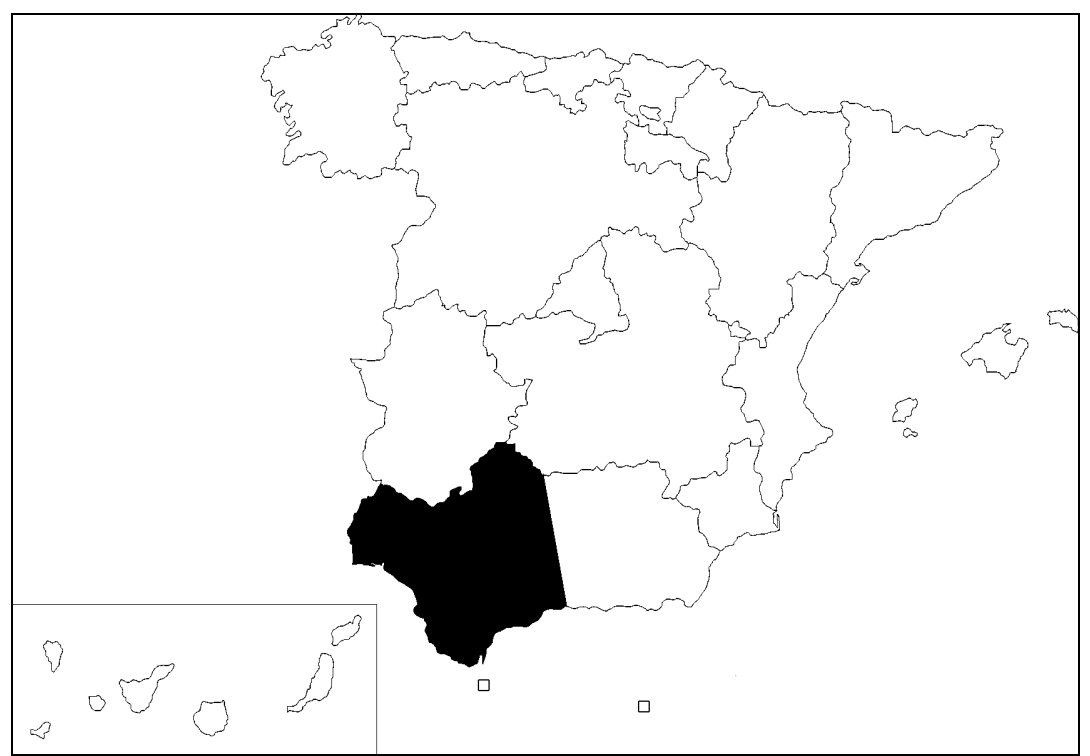

Map 1. Phenomenon inside Spain

The literature about this phenomenon is found in works on historic grammars or in monographs dealing with the Andalusian dialect (Mondéjar 1974; Lapesa 2000; Cano 2004; Penny 2004; Ménendez Pidal 2005). These authors state that this particularity is witnessed in the districts of Córdoba, Málaga, Cádiz, Huelva and Seville (see Maps 1 and 2).

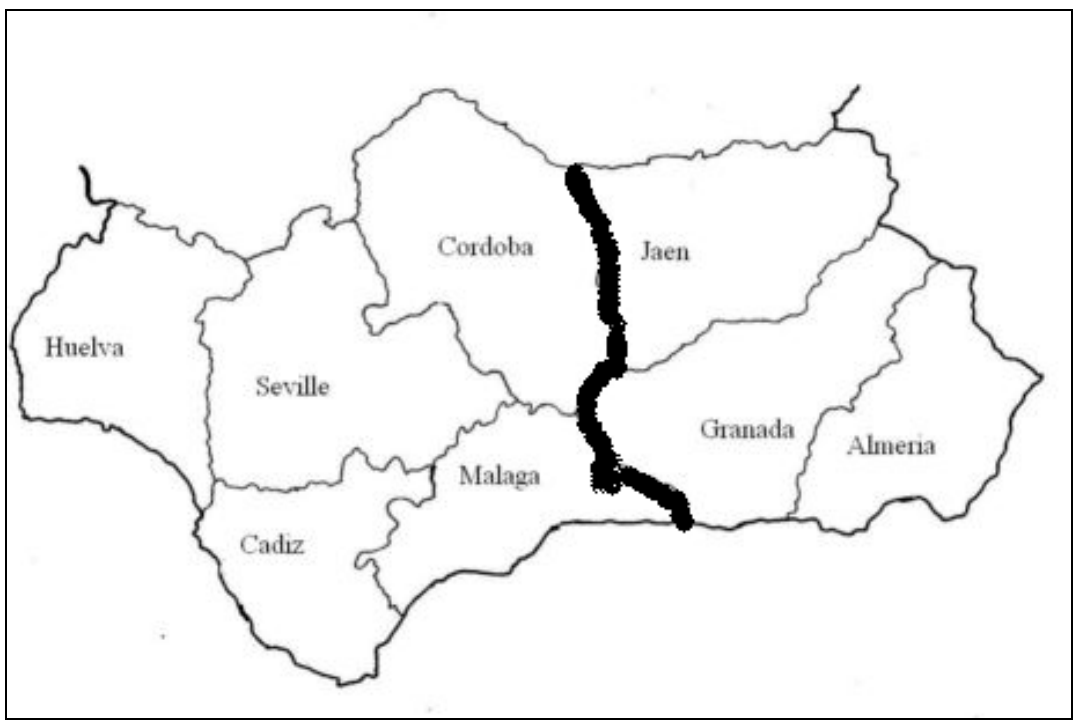

Map 2. Phenomenon inside Andalusia

They also affirm that it is stigmatised and it has always been considered as illiterate and rural. Furthermore, ustedes always agrees in $2^{\text {nd }}$ person plural, unless the 
verb is tensed in preterite perfect simple. In this case, the $3^{\text {rd }}$ person is preferred. Reflexive particles agree in $3^{\text {rd }}$ person, as well. All of them point out that the possessive has changed into a prepositional phrase de ustedes, instead of the normative $3^{\text {rd }}$ person su or the $2^{\text {nd }}$ person vuestro (see Table 4). Finally, they notice that the adoption of one specific person agreement is not based on the degree of politeness of the communicative situation.

\begin{tabular}{|l|l|l|l|l|l|l|}
\hline & $\begin{array}{l}\text { Stressed } \\
\text { pronoun }\end{array}$ & Verb & $\begin{array}{l}\text { Preterite } \\
\text { perfect } \\
\text { simple }\end{array}$ & Possessive & Reflexive & Object \\
\hline Formality & Ustedes & $2^{\text {nd }}$ & $3^{\text {rd }}$ & $\begin{array}{l}3^{\text {rd }} / \text { de } \\
\text { ustedes }\end{array}$ & $3^{\text {rd }}$ & $2^{\text {nd }}$ \\
\hline Informality & Ustedes & $2^{\text {nd }}$ & $3^{\text {rd }}$ & $\begin{array}{l}3^{\text {rd }} / \text { de } \\
\text { ustedes }\end{array}$ & $3^{\text {rd }}$ & $2^{\text {nd }}$ \\
\hline
\end{tabular}

Table 4. Allocutives person agreements in Andalusia

As for many other phenomena, whenever a linguistic change emerges, it does not do so in all the syntactic contexts it should (Labov 1995; Corbett 2006). Voseo (the use of medieval pronoun vós to address one person under an informal context) first arose in the stressed pronoun and its inflections spread little by little, first in the imperative, then in the present indicative, later in the present subjunctive and they are not attested yet in clitics and possessives (Fontanella de Weinberg 1979; Abadía de Quant 1992; Bertolotti \& Coll 2003). In the case of ustedes, the $3^{\text {rd }}$ person was first employed in the stressed pronoun but it has not forced all syntactic elements to be inflected in $3^{\text {rd }}$ person yet, as I will show hereinafter. Third person, then, is expected to extend gradually until it is established in all the ustedes syntactic references.

\subsection{Geolinguistic corpus}

The most recent information available on this phenomenon can be found in the Linguistic Atlas of the Iberian Peninsula (ALPI, in the Spanish acronym), uploaded on Heap (2003). This dialect atlas was conceived by Menéndez Pidal and carried out by a group of researchers, who travelled throughout the Iberian Peninsula, with the aim of 
collecting the phonological, lexical and morphosyntactic phenomena of all the Romance languages in the peninsula. Their interviews were made between the 1920's and the 1950's and these consisted of pre-established sentences and words that informants had to repeat based on their vernacular variety. The lack of spontaneity could have tainted in the informant's response. However, we have to keep in mind that they did not count with the gadgets we do nowadays and plenty of their linguistic findings have been confirmed later on.

Within these pre-established sentences, there were eleven with reference to a second person plural. These provided data about the stressed pronoun, the reflexive particle, the accusative pronoun, as well as main verbs tensed in imperative and present indicative. There was also a sentence with an embedded verb. Thanks to this important work, some information on this phenomenon could be disseminated, regarding three parameters: its geographic diffusion pattern, its grammatical behaviour and its pragmatic incidence.

In terms of its geographic extension, the ustedes phenomenon was attested in West Andalusia, concretely in the provinces of Cádiz, Seville, Huelva, Córdoba (except the northern part) and Málaga (excepting the eastern part). Moreover, its diffusion pattern followed the wave model, as postulated by Chambers \& Trudgill (1980) or Wolfram \& Schilling-Estes (2003). This model states that a specific linguistic phenomenon arises in a specific geographic point, called focus or epicentre, in which all the further innovations concerning the phenomenon will arise first too.

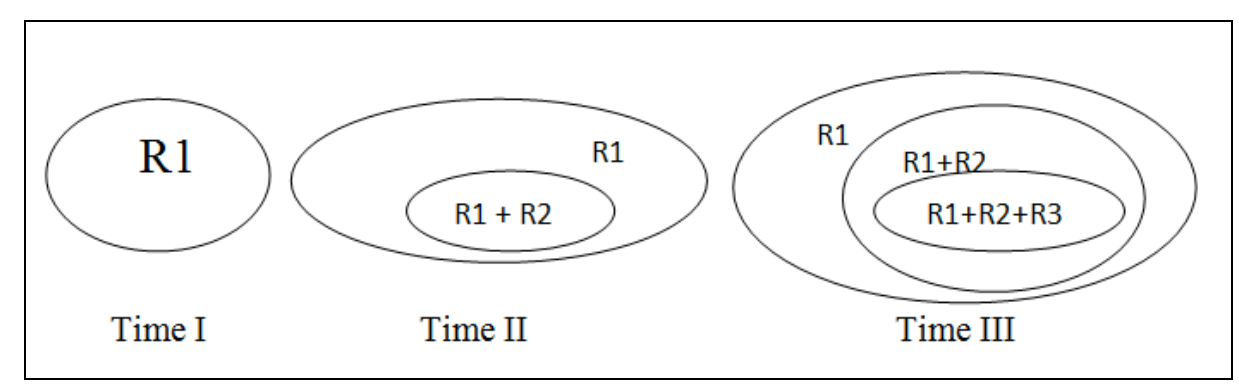

Figure 1. Wave model pattern (Wolfram \& Schilling-Estes 2003: 714)

In Figure 1, R represents the rule change within an innovation. The hypothesis predicts that in an innovation in which three changes have been produced R1 arises in a specific point where it will be diffused from toward its outlying area. When R1 
extends to the periphery, R2 will have appeared in the same point where R1 arose before. In an ulterior evolution, R2 will have reached the outlying area of the focus, while R1 will have shifted over to a more distant area, and, at the same time, R3 will have emerged in the focus.

Additionally, this pattern presents three tendencies described in Chambers \& Trudgill (1980: 167-168), and shown as follows:

a) If, of two linguistic forms, one is found in isolated areas and the other in areas more accessible, the former is the older.

b) If, of two linguistic forms, one is found in peripheral areas and the other in central areas, then the former is the older.

c) If, of two forms, one is sued over a larger area than the other, then that is the older.

If all this information is applied to the phenomenon under investigation, based on the ALPI data drawn in Map 3, several conclusions can be remarked. Level 1 is characterised by change 1; level 2 by changes 1 and 2; level 3, by changes 1, 2 and 3, and, finally, level 4 has reached four changes. This spatial diffusion demonstrates that this phenomenon arose in Cádiz and southern Seville, since it is the area that has diffused all the changes occurring in it. The more proximate to this area, the more changes shared; the less proximate, the fewer changes shared, until the phenomenon fades.

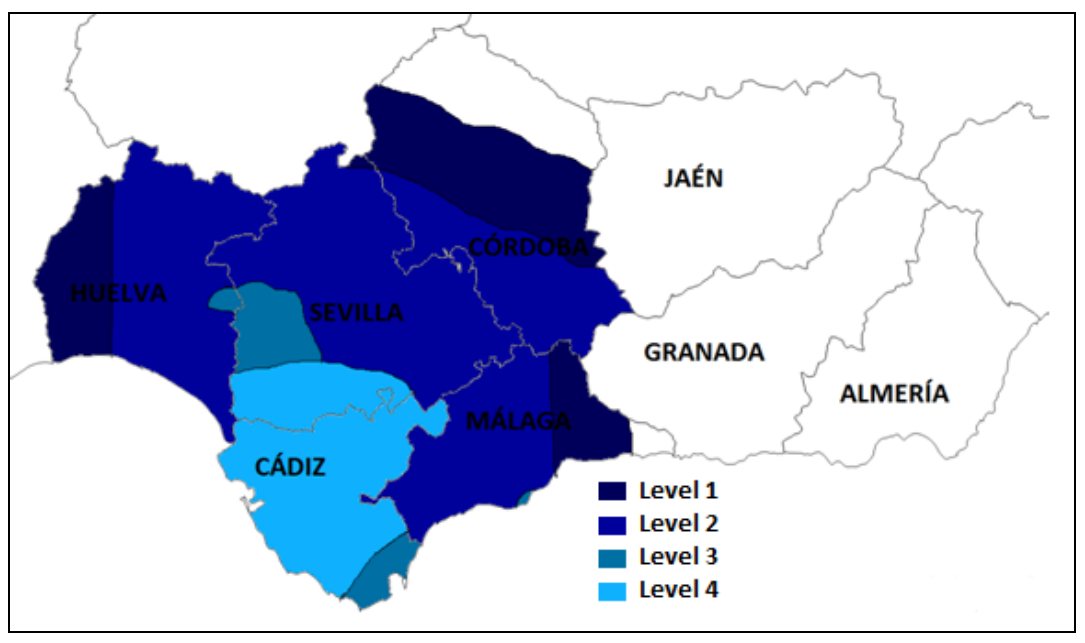

Map 3. Andalusia geographic diffusion pattern (Lara 2012: 85) 
In terms of its grammatical behaviour, this phenomenon predicts the extension of the $3^{\text {rd }}$ person plural in all the syntactic elements anchoring ustedes. Since ustedes induces $3^{\text {rd }}$ person plural inflections, these must appear gradually, until it is settled in all the elements with reference to ustedes. According to Map 3, the extension of the $3^{\text {rd }}$ person follows an implicative hierarchy represented in 1.

1. Stressed pronoun $>$ reflexive $>$ accusative $>$ embedded verb

The continuum must be read as follows: the adoption of the third person in a specific piece implies its appearance in the elements on the left. So, if the third person is attested in the accusative, it also arises in the reflexive and, of course, in the stressed pronoun. This extension goes rightwards in the hierarchy.

In terms of pragmatics, the informant's grammatical agreement did not change based on the degree of politeness. Ustedes was used both for formality and informality. The adoption of third person or the maintenance of second person inflections was not affected by the type of addressees.

\section{Corpus and methodology}

Second person plural pronouns are the least likely to appear in a conversation. The sociolinguistic interview, thus, is not useful for us to collect this kind of data, since the informants tend to speak about themselves, about other people's lives or they are sure to address one interviewer only, although there may be two people posing questions.

In order to compensate the shortcomings arisen in the pre-established sentences and questionnaires, as well as the low probability of appearance of $2^{\text {nd }}$ person plural inflections through other more recent methods, I designed another type of prompting. All the informants analysed collaborated in the activity created expressly to obtain as many second person inflections as possible. This consisted of having the informants dub a series of scenes compiled from the popular sitcoms Friends and the Spanish Aquí no hay quien viva ('It is impossible to live here'). Both sitcoms usually show one character talking to more than one person at the same time. Besides, their characters 
have to speak to any kind of addressees, that is, elderly people, bosses, flatmates, friends, neighbours, acquaintances, children, etc. It is, therefore, a great chance to analyse possible mismatches in the informants' grammatical agreement, having also into account the formality of the given situation. The informants had to dub the character addressing the others, according to a previous synopsis I described. Each scene prompted the emergence of a specific syntactic element (verb, reflexive, object clitics, and so on) thanks to the synopsis. I compiled several scenes for each syntactic piece to appear, in order to ensure the quantitative part of the corpus and its further analysis. I did not condition the informants, since the description of the scene was always carried out with references to third persons, so no second person plural was previously mentioned at all. All the fieldwork was carried out along the year 2012.

\section{Analysis}

My corpus is hence constituted by 4,500 examples of second person plural inflections, from around 250 informants. The occurrences were processed by the computer programme SPSS and analysed statistically, based on the following social factors: sex, age, educational level and geographic area. Below, I will detail the number of people, depending on the social factor analysed, who choose $U$ (ustedes), that is, the vernacular alternative, or V (vosotros), that is, the standard. Furthermore, I will point out the real statistical significance of each factor (Pearson's chi squared test), in order to define the true social influences affecting this phenomenon and I will apply a logistic regression to the variables. Eventually, I will show three maps of the most significant variables. Each map is drawn regarding the proportion of usage of the vernacular particularity: a) less than a third of informants; b) around two thirds; c) most of the informants.

a) Sex

Informants in the ALPI were male only. I chose to find whether there was any difference between sexes, since a number of studies have proved that women usually 
lead the prestigious linguistic change (Labov 1966; Labov 1978; Chambers \& Trudgill 1980; Chambers 1995; Blas Arroyo 2005).

In Figure 2, women are more inclined to employ the standard pattern, in comparison with men, who prefer the vernacular particularity. However, this advantage is quite slight and both genders are characterised by the same linguistic behaviour.

Table 5. Sex

\begin{tabular}{|c|c|r|r|r|}
\hline \multicolumn{4}{|c|}{ U / V * Sex } \\
\hline \multicolumn{2}{|c|}{} & \multicolumn{2}{|c|}{ Sex } & \multirow{2}{*}{ Total } \\
\cline { 3 - 4 } \multicolumn{2}{|c|}{} & Men & Women & \\
\hline \multirow{2}{*}{ U / V } & U & 65 & 67 & 132 \\
\cline { 2 - 5 } & $\mathrm{V}$ & 42 & 55 & 97 \\
\hline Total & 107 & 122 & 229 \\
\hline
\end{tabular}

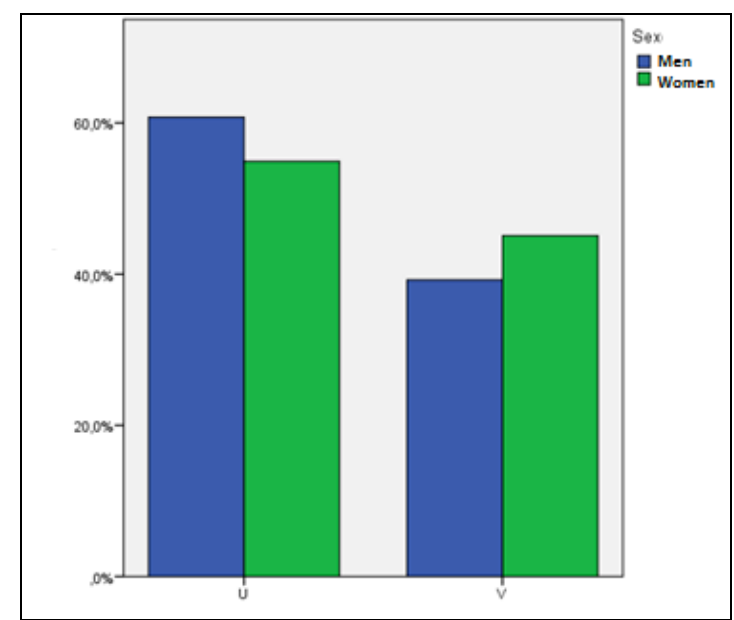

Figure 2. Sex

Besides, the Pearson's chi squared test applied to variable sex did not arrive at the statistical significance, although it reached the edge of it. On the whole, women seem to be slightly closer to the prestige, such as Labov (1966 and 1978) or Hovarth (1985) have attested.

b) Age

Age has nearly always been key in the leadership or stigmatisation of a given linguistic phenomenon. Although in the ALPI, informants were older than fifty, I also 
interviewed younger speakers. All my informants are divided in three groups, based on their age: younger than 30, from 30 to 60 , older than 60 .

Table 6. Age

\begin{tabular}{|l|l|r|r|r|r|}
\hline \multicolumn{7}{|c|}{ U / V * Age } \\
\hline \multirow{2}{*}{} & \multicolumn{3}{|c|}{ Age } & \multirow{2}{*}{ Total } \\
\cline { 2 - 5 } & -30 & $30-60$ & $60-$ & \\
\hline \multirow{2}{*}{ U / V } & $U$ & 55 & 48 & 29 & 132 \\
\cline { 2 - 5 } & $\mathrm{V}$ & 37 & 55 & 5 & 97 \\
\hline Total & 92 & 103 & 34 & 229 \\
\hline
\end{tabular}

\section{Table 6. Age}

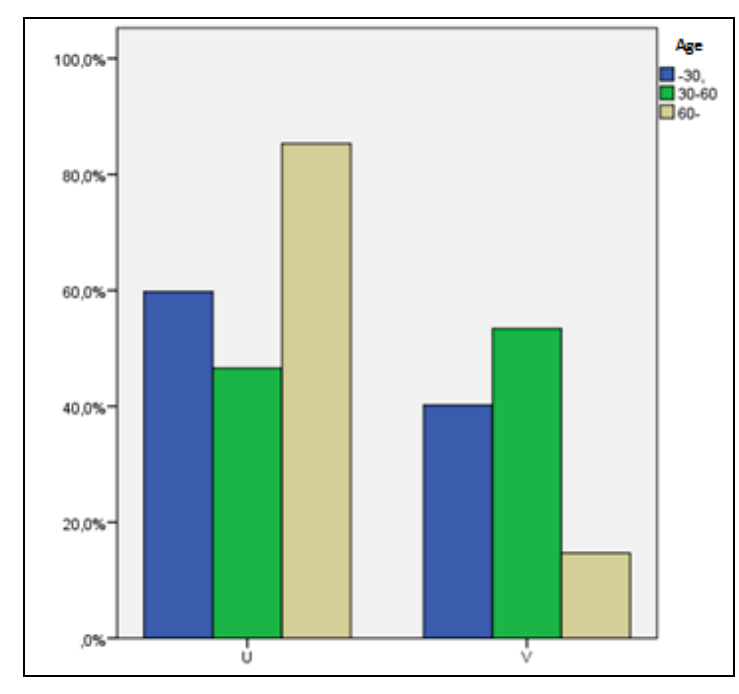

Figure 3. Age

Figure 3 shows that middle-aged speakers mostly prefer the prestigious form, whereas younger ones are more conservative. On the other hand, elderly people still use overwhelmingly the dialect system of pronouns. The fact that younger speakers are more vernacular than their parents can be due to the theory of the linguistic market, stated by Bourdieu (1978) and attested in other phenomena, like in Macaulay's (1977) study about the elision of [t] around the Glasgow area and Seara's (2000) investigation on the $1^{\text {st }}$ plural pronoun innovation in Portuguese, a gente in the place of the normative nós. This theory postulates that the people who are performing any job have to get used to prestigious patterns, also in language, in order to succeed in their careers. Whereas young speakers attend high school or university, the majority 
of the middle-aged speakers already works, so they have to adopt the patterns society expects them to have.

The chi squared test for this variable resulted in a high significant factor in the selection of the prestigious or the vernacular usage.

\section{c) Educational background}

The educational background is narrowly related to the age since the older the informants are, the less likely to have a high educational level. Society has changed in Spain in the last decades. Elderly people did not use to go to school, while middle-aged people started to reach university little by little. Nowadays, school is obligatory until 16 years old and a high proportion continues to study in universities.

\begin{tabular}{|l|l|r|r|r|}
\hline \multicolumn{4}{|c|}{ U / V * Educational level } \\
\hline \multirow{2}{*}{\multicolumn{2}{|c|}{}} & \multicolumn{2}{|c|}{ Educational level } & \multirow{2}{*}{ Total } \\
\cline { 2 - 4 } \multicolumn{2}{|c|}{ Low } & \multicolumn{1}{c|}{ High } & \\
\hline \multirow{2}{*}{$\mathrm{U} / \mathrm{V}$} & $\mathrm{U}$ & 116 & 16 & 132 \\
\cline { 2 - 5 } & $\mathrm{V}$ & 53 & 44 & 97 \\
\hline Total & 169 & 60 & 229 \\
\hline
\end{tabular}

Table 7. Educational level

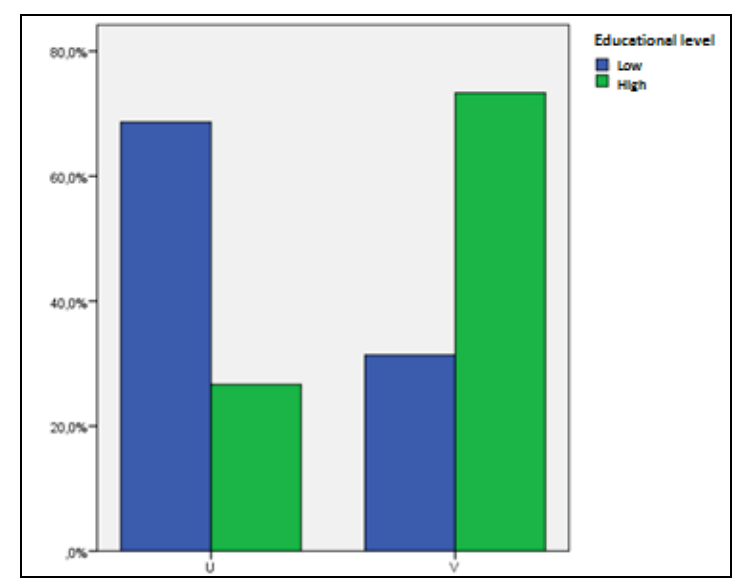

Figure 4. Educational level 
In figure 4, speakers with a high educational level try to adopt the standard usage of pronouns. They choose mostly the standard pattern and are clearly differentiated from the people who have not reached university, regardless their age.

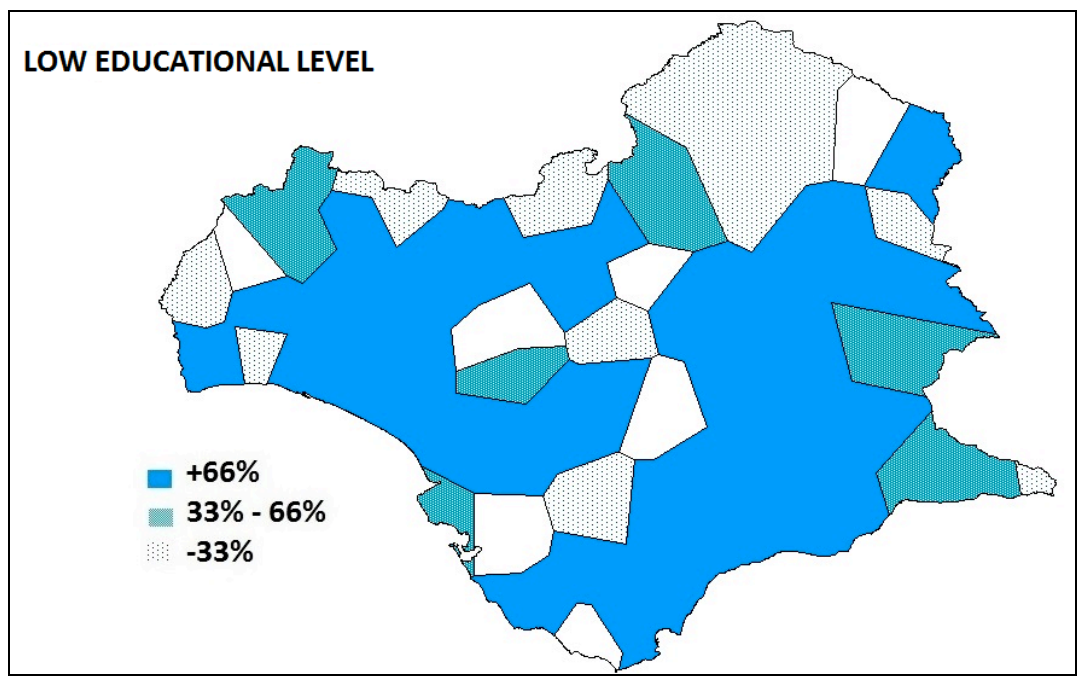

Map 4. Low educational level

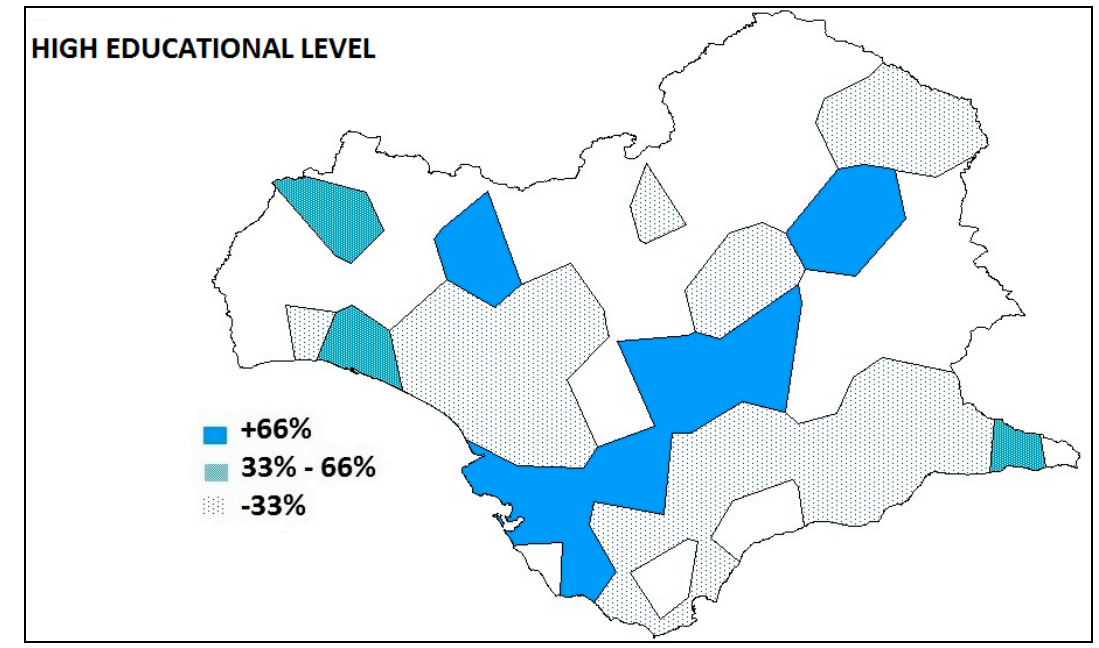

Map 5. High educational level

Education has revealed as a key in the use of the prestigious forms, as Labov (1978) or Chambers's (1997) study on the complementizer que in the Montréal French have demonstrated. As for age, the result of the chi squared was highly significant, and therefore, education is a key factor to employ ustedes only or to tell apart the degree of politeness through different pronouns (see Maps 4 and 5). 
d) Geographic area

The analysis based on the geography of the phenomenon has been double. It has been divided in two parameters: on the one hand, the province where this phenomenon is said to be attested and was actually attested by the ALPI; on the other hand, the zones arisen in the geographic diffusion pattern taken from ALPI data, that is, zones from 1 up to 4 (see Map 3). I have interviewed in villages where this phenomenon was not witnessed a century ago, in case it has spread (zone 0). Moreover, I aimed to find the current diffusion pattern, in case the wave model does not work any longer.

\begin{tabular}{|c|c|c|c|c|c|c|c|}
\hline \multicolumn{8}{|c|}{$\mathrm{U} / \mathrm{V}$ * Province } \\
\hline & & \multicolumn{5}{|c|}{ Province } & \multirow[t]{2}{*}{ Total } \\
\hline & & Cádiz & Córdoba & Huelva & Málaga & Seville & \\
\hline \multirow{2}{*}{$\mathrm{U} / \mathrm{V}$} & U & 32 & 13 & 22 & 25 & 40 & 132 \\
\hline & $\mathrm{V}$ & 18 & 15 & 16 & 22 & 26 & 97 \\
\hline \multicolumn{2}{|l|}{ Total } & 50 & 28 & 38 & 47 & 66 & 229 \\
\hline
\end{tabular}

Table 8. Province

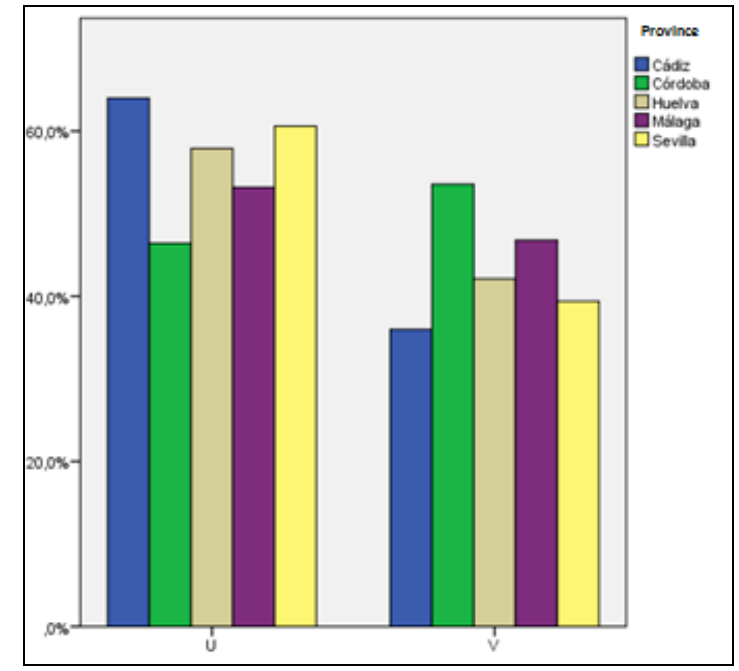

Figure 5. Province 
Dialectologia. Special issue, V (2015), 241-260.

ISSN: 2013-2247

\begin{tabular}{|c|c|c|c|c|c|c|c|}
\hline \multicolumn{8}{|c|}{$\mathrm{U} / \mathrm{V} *$ Zone ALPI } \\
\hline & & \multicolumn{5}{|c|}{ ZONE ALPI } & \multirow[t]{2}{*}{ Total } \\
\hline & & 0 & 1 & 2 & 3 & 4 & \\
\hline \multirow{2}{*}{ U / V } & U & 0 & 16 & 63 & 18 & 35 & 132 \\
\hline & $\mathrm{V}$ & 8 & 19 & 33 & 22 & 15 & 97 \\
\hline \multicolumn{2}{|l|}{ Total } & 8 & 35 & 96 & 40 & 50 & 229 \\
\hline
\end{tabular}

Table 9. Zone ALPI

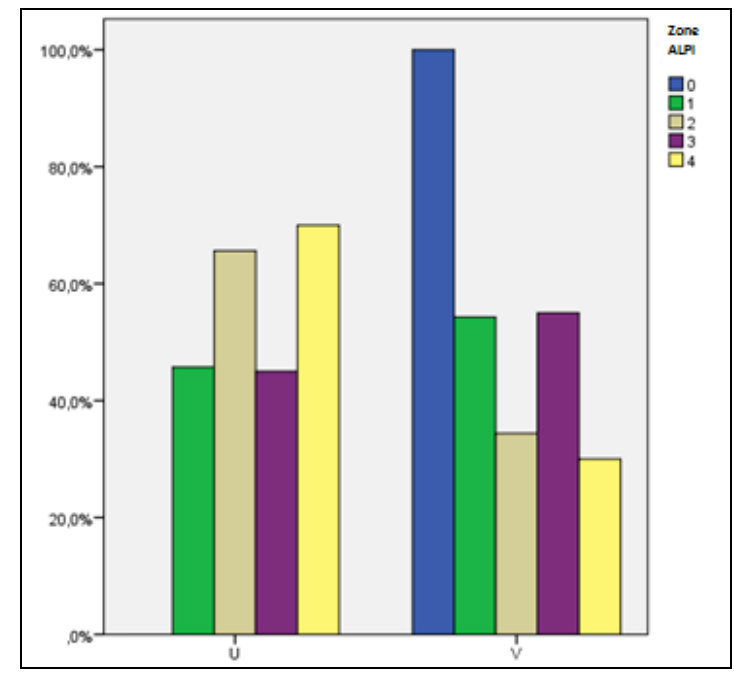

Figure 6. Zone ALPI

\begin{tabular}{|l|l|r|r|r|}
\hline \multicolumn{4}{|c|}{ U / V * POP 500.000 } \\
\hline \multirow{2}{*}{} & \multicolumn{2}{|c|}{ POP 500.000} & \multirow{2}{*}{ Total } \\
\cline { 2 - 4 } \multicolumn{2}{|c|}{} & -500000 & 500000 & \\
\hline \multirow{2}{*}{ U / V } & U & 124 & 8 & 132 \\
\cline { 2 - 5 } & $\mathrm{V}$ & 81 & 16 & 97 \\
\hline Total & 205 & 24 & 229 \\
\hline
\end{tabular}

Table 10. Population 


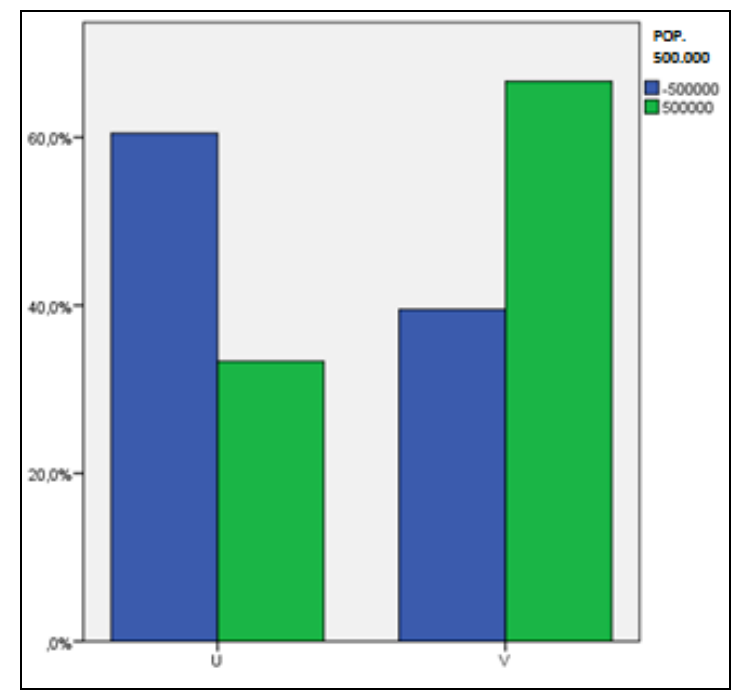

Figure 7. Population

On the one hand, Cádiz and Seville are the districts with a higher proportion of maintaining the phenomenon. Córdoba and Málaga behave the opposite way, and the district of Huelva swings between either the standard tendency or the vernacular one (see Figure 5). This phenomenon has not extended further than it had almost one hundred years earlier. Indeed, it has not been witnessed in some villages where ALPI collected the usage of this particularity. In that sense, the phenomenon has decreased in geographical terms. This regression has taken place in northern Córdoba.

On the other hand, there is a strong variation also in geography. Nevertheless, the conclusion is that the further away from the focus, the likelier to imitate the standard usage. The closer to the ALPI focus or epicentre, that is, Cádiz and southern Seville, the likelier to keep the vernacular employment (see Figure 6 and Map 6). 


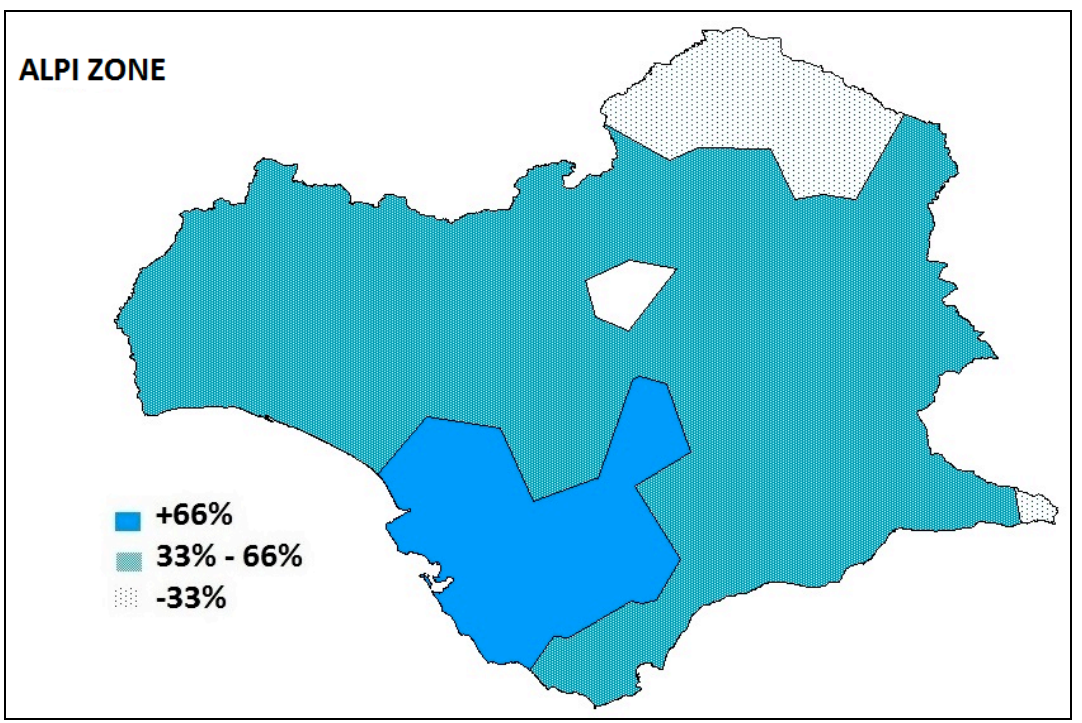

Map 6. Zone ALPI

Lastly, I have analysed statistically the proportion of this phenomenon, based on the population of the locality. Despite the high variation, there seems to be a clear distinction between large cities, such as Seville and Málaga, and towns and villages (see Figure 7). The former try to adopt the standard usage, while the latter are more conservative and prefer to maintain the vernacular phenomenon. Of all the divisions based on the population, the chi squared test gave a high significance only in the case of the differentiation between large cities (more than half a million inhabitants) and towns and villages (less than half a million inhabitants). However, in all figures related to the population, the smaller the town was, the likelier it kept the vernacular phenomenon. This may lead to the conclusion of a new kind of spatial diffusion of the standard usage in detriment of the dialect particularity: the gravity model. This pattern predicts that a given linguistic phenomenon will extend depending on the population density of two points. According to these authors:

Changes are most likely to begin in large, heavily populated cities, which have historically been cultural centres. From there, they radiate outward, but not in a simple wave pattern. Rather, innovations first reach moderately sized cities, which fall under the area of influence of some large, focal city, leaving nearby sparsely populated areas unaffected. Gradually, innovations filter down from more populous areas to those of lesser population, affecting rural areas last, even if such areas are 
quite close to the original focal area of the change. (Wolfram \& Schilling-Estes, 2003: 724)

\section{e) Regression analysis}

The multivariate analysis carried out with all the variables taken into account, has resulted in a hierarchical series, in which the educational level is the main social factor that influences on the selection between either the vernacular particularity or the standard pattern. After this, the ALPI zone is key to choose one of the alternatives: the more proximate to the focus, the more vernacular. Finally, the distinction between towns bigger than half a million inhabitants and the rest interferes in the tendency towards the standard usage or the maintenance of the dialect phenomenon. The bigger towns are, the more inclined they are to the prestige pattern. Age, although it had a significant relevance when applied the Pearson's chi squared test, was narrowly correlated to educational background. As elderly people did not attend school in Spain some decades ago, they belong to the least literate group of society: they were the more vernacular. The group of people up to 60 years old is constituted by speakers that have or not attended university. The higher their educational background is, the more standard they behave linguistically.

\section{Conclusion}

Nowadays, Andalusian speakers are characterised by a high alternation between the standard and the vernacular, regarding the second person plural pronouns system. There is a dramatic tendency toward the prestige and the standard usage, and this behaviour is led, above all, by people with a high educational background, and who live in large urban environments. Additionally, this new change seems to spread following a gravity model, unlike the wave diffusion pattern attested last century. The standard pressure is first witnessed in the populous cities of Seville and Málaga. Therefore, the smaller towns are, the likelier they maintain the vernacular phenomenon. Although women have a slight inclination toward standardisation, it has not resulted significant 
in the statistical analysis. Middle-aged informants were the closest to the prestige pattern. However, the logistic regression correlated the factor age to educational background. Therefore, although elderly people are overwhelmingly vernacular, they did not attend school in their childhoods. Younger speakers tend to the standard or not, depending on their educational level, regardless their age. As the youngest group, the one up to 30 years old, is formed by people who have not reached the age to attend university or they have not completed their studies, they have kept the vernacular particularity in a higher proportion than middle-aged people, whose educational background is usually higher.

Linguistically, in the dialect phenomenon, the $3^{\text {rd }}$ person plural extends across an implicative continuum. The stressed pronoun is the one where it is attested before, then it passes to the reflexive, verb and it finishes in the accusative and dative clitics, in this order. Finally, possessives are the syntactic pieces with the least probability to be inflected in $3^{\text {rd }}$ person. This hierarchy responds to Blake's grammatical relations, as well as the distinction between concord and index postulated by Wechsler \& Zlatic. Lastly, Corbett's statements about syntactic and semantic agreement, as well as the position of controller versus target within the sentence have also been relevant in the spread of the innovative grammatical agreement.

\section{References}

ABADÍA DE QUANT, I. (1992) "La relación pronominal-verbal de segunda persona singular en el español de Corrientes durante el siglo XIX, su comparación con la situación en Buenos Aires", Revista argentina de lingüística, 8, 31-46.

Bertolotti, V. \& M. COlL (2003) "A synchronical and historical view of the tú/vos option in the Spanish of Montevideo", in S. Montrul \& F. Ordóñez (eds.), Linguistic theory and language development in Hispanic languages, Somerville: Cascadilla Press, 1-12.

Blas ARroyo, J. L. (2005) Sociolingüística del español, Madrid: Cátedra.

BouRdieU, P. (1978) "El mercado lingüístico", in Questions de sociologie, Paris: Minuit, 121-137.

CANO, R. (coord.) (2004) Historia de la lengua española, Barcelona: Ariel.

Chambers, J.K. \& P. TRUdGill (1980) Dialectology, Cambridge: Cambridge University Press. 
ChAMBers, J. K. (1995) Sociolinguistic theory. Language in society series, 22, Oxford: Balckwell.

CHAMBERS, J.K. (1997) Sociolinguistic theory, Malden: Blackwell,

FontANelLa de WeinBerg, B. (1979) "La oposición cantes/cantés en el español de Buenos Aires", Thesaurus, XXXIV, 72-83.

HeAP, D. (2003) Atlas Lingüístico de la Península Ibérica (ALPI). University of Western Ontario, Canada [http://westernlinguistics.ca/alpi/].

HORVARTH, B. (1985) Variation in Australian English: the sociolects of Sydney, Cambridge: Cambridge University Press.

LABOV, W. (1966) The social stratification of English in New York City, Washington DC: Center for Applied Linguistics.

LABOV, W. (1978) Sociolinguistic patterns, Philadelphia: University of Pennsylvania Press.

LABOV, W. (1995) Principles of linguistic change, Cambridge: Blackwell.

LAPESA, R. (2000) Estudios de morfosintaxis histórica del español, Madrid: Gredos.

LARA, V. (2010) El uso de ustedes por vosotros en Andalucía occidental, Madrid: Universidad Autónoma de Madrid.

LARA, V. (2012) "Ustedes instead of vosotros and vocês instead of vós: an analysis through the Linguistic Atlas of the Iberian Peninsula (ALPI)", Dialectologia, Special Issue, 3, 57-93. <http://www.publicacions.ub.edu/revistes/dialectologiaSP2012/>

MACAULAY, RKS. (1977) Language, social class and education: a Glasgow study, Edinburgh: Edinburgh University Press.

MENÉndez PIDAL, R. (2005) Historia de la lengua española, Madrid: RAE / Fundación Menéndez Pidal.

MondÉJAR, J. (1974) El verbo andaluz: formas y estructuras, Málaga: Ágora.

PENNY, R. (2004) Variación y cambio en español, Madrid: Gredos.

SEARA, I. C. (2000) "A variação do sujeito nós e a gente na fala florionapolitana", Organon, 14, 179-194.

Wolfram, W. \& N. SChilling-Estes (2003) "Dialectology and Linguistic Diffusion", in D. J. Brian \& R. D. Janda (eds.), The Handbook of Historical Linguistics, Malden: Blackwell, 713-735. 